\title{
Aktivitas Antioksidan, Kadar Vitamin C dan Derajat Keasaman pada Susu Kambing Fermentasi dengan Menggunakan Lactobacillus rhamnosus dan Penambahan Jus Buah Bit (Beta vulgaris L)
}

(Antioxidant Activity, Vitamin C Levels and Degree of Acidity of Fermentation Goat's Milk Using Lactobacillus rhamnosus and Addition of Beetroot Juice

\author{
(Beta vulgaris $L$.)
}

\author{
Putri $^{1}$, Yurliasni ${ }^{1}$, Zuraida Hanum ${ }^{1}$,* \\ ${ }^{1}$ Program Studi Peternakan, Fakultas Pertanian, Universitas Syiah Kuala \\ *Corresponding author: yurliasni@unsyiah.ac.id
}

\begin{abstract}
Abstrak. Penelitian ini betujuan untuk mengetahui aktivitas antioksidan, kadar vitamin $\mathrm{C}$ dan nilai $\mathrm{pH}$ susu kambing fermentasi dengan menggunakan Lactobacillus rhamnosus dan penambahan jus buah bit (Beta vulgaris L). Rancangan yang digunakan adalah Rancangan Acak Lengkap (RAL) yang terdiri dari 5 perlakuan dan 4 ulangan sehingga diperoleh 20 unit percobaan. Perlakuan yang diberikan terdiri dari: P0: (kontrol) $0 \%$ jus buah bit, P1: $2 \%$ jus buah bit, P2 :4\% jus buah bit, P3: $6 \%$ jus buah bit, P4: $8 \%$ jus buah bit. Parameter yang diukur dalam penelitian ini adalah uji $\mathrm{pH}$, uji kadar vitamin $\mathrm{C}$ dan aktivitas antioksidan. Hasil penelitian ini menunjukkan bahwa susu kambing fermentasi menggunakan Lactobacillus rhamnosus dan penambahan jus buah bit berpengaruh sangat nyata $(\mathrm{P}<0,01)$ terhadap nilai $\mathrm{pH}$, dan pada aktivitas antioksidan menunjukkan dengan penambahan jus buah bit mampu meningkatkan golongan aktivitas antioksidan (IC50) susu kambing fermentasi dari golongan antioksidan sedang menjadi golongan antioksidan kuat. Sedangkan pada hasil uji kadar vitamin C menunjukkan bahwa penambahan jus buah bit tidak berpengaruh nyata $(\mathrm{P}>0.05)$ terhadap kadar vitamin $\mathrm{C}$ susu kambing fermentasi.
\end{abstract}

Kata kunci : Susu Kambing ; Buah bit (Beta vulgaris L); Lactobacillus rhamnosus; Kualitas susu kambing fermentasi

Abstract. This study aims to determine the antioxidant activity, vitamin $\mathrm{C}$ content and $\mathrm{pH}$ value of fermentes goat milk using Lactobacillus rhamnosus and the addition of fruit juice beet (Beta vulgaris $\mathrm{L}$ ). The design used completely Randomized (CRD) consisting of 5 treatments and 4 replications so that the obtained 20 units. The treatment consists of: P0: (control) $0 \%$ juice fruit bits, P1: $2 \%$ fruit juice beets, P2 :4\% fruit juice beets, P3: S4\% fruit juice beets, $\mathrm{P} 4: 8 \%$ fruit juice bits. The parameters measured were $\mathrm{pH}$, the levels of vitamin $\mathrm{C}_{\text {and }} \mathrm{IC}_{50}$ of antioxidant activity. The results showed that goat milk fermented using Lactobacillus rhamnosus and the addition of Beets fruit juice very significantly $(\mathrm{P}<0.01)$ effect very significant effect $(\mathrm{P}<0.01)$ on $\mathrm{pH}$ value, on the antioxidant activity showed that with the addition of fruit juice beet able to increase the class of antioxidant activity (IC50) of goat milk fermented from the class of antioxidants becoming a group of powerful antioxidants. While on the test results the levels of vitamin $\mathrm{C}$ showed that the addition of fruit juice the beets do not significantly effect $(\mathrm{P}>0.05)$ on the levels of vitamin $\mathrm{C}$.

Keywords: Goat's milk ; Fruit beet (Beta vulgaris L); Lactobacillus rhamnosus; Quality of goat milk fermented

\section{PENDAHULUAN}

Antioksidan adalah senyawa yang mampu meredam radikal bebas di dalam tubuh (Ahmad et al., 2012). Radikal bebas (Reactive Oxygen Species) merupakan molekul yang salah satu elektronnya tidak berpasangan oleh sebab itu sifatnya sangat tidak stabil dan sanggat reaktif (Sen et al., 2010; Turan, 2010). Reaksi radikal bebas yang berlebihan di dalam tubuh dapat mengakibatkan terganggunya produksi DNA, aktivitas pembuluh darah, lipid pada dinding sel dan mengganggu produksi prostaglandin dan protein lainya seperti enzim yang terdapat di dalam tubuh (Werhdasari, 2014). Antioksidan berperan membatasi efek dari reaksi 
oksidasi dalam tubuh, serta mampu menstabilkan radikal bebas dengan melengkapi kekurangan elektron (Winarsi, 2007).

Antioksidan berdasarkan sumbernya digolongkan menjadi 2 (dua) yakni: antioksidan alami dan sintetis, antioksidan alami dapat ditemukan pada sayuran dan buah-buahan sedangkan antioksdan sintetis biasanya digunakan oleh industri seperti buthylated hydroxsianisol (BHA), buthylated hydroxytoluene (BHT) dan ters-buthylated hidroquinone (TBHQ) yang secara efektif dapat menghambat radikal bebas. Namun adanya kekhawatiran dalam penggunaan antioksidan sintetis dikarenakan dapat bersifat racun di dalam tubuh jika digunakan secara berlebihan (Wulansari, 2018). Pada dasarnya di dalam tubuh manusia sudah terdapat antioksidan alami, akan tetapi tidak cukup efektif dalam menangkal radikal bebas (Sen et al., 2010). Oleh sebab itu tubuh membutuhkan asupan yang mengandung antioksidan alami yaitu susu yang mengandung beberapa antioksidan, seperti laktoferin, asam askorbat, $\alpha$ tokoferol, dan karotenoid (Lindmark dan Akson, 2000).

Susu kambing merupakan salah satu jenis susu yang memiliki kandungan nutrisi yang lengkap, kadar air tinggi tingkat keasaman rendah, memiliki antiseptik alami sebagai anti bakteri. Pada susu kambing butiran lemaknya lebih kecil bila dibandingkan dan susu sapi oleh sebab itu susu kambing lebih mudah dicerna oleh tubuh (Sultama, 2009). Namun demikian aktivitas antioksidan di dalam susu masih terbilang rendah sehingga untuk meningkatkan kandungan antioksidannya perlu dilakukan proses fermentasi. Fermentasi merupakan salah satu metode yang terbukti secara signifikan berpengaruh terhadap peningkatan aktivitas antioksidan susu (Abubakar et al., 2012).

Susu fermentasi diolah dengan menggunakan bakteri probiotik sebagai starternya. Dalam hal ini probiotik yang digunakan adalah bakteri dari golongan asam laktat (BAL) yaitu Lactobacillus rhamnosus. Pada umumnya minuman probiotik dikombinasikan dengan buah buahan yang memiliki kandungan gizi yang baik bertujuan untuk meningkatkan nilai nutrisi dan menambah citarasa, serta meningkatkan aktivitas antioksidan susu fermentasi. Antioksidan alami banyak terdapat pada tumbuh-tumbuhan, sayur-sayuran dan buah-buahan (Winarsi, 2007). Salah satu jenis buah yang dapat dikombinasikan dengan susu fermentasi adalah buah bit (Beta Vulgaris L), buah bit (Beta Vulgaris L) merupakan salah satu jenis bahan pagan lokal yang terkenal tinggi kandungan vitamin $\mathrm{C}$ bermanfaat untuk kesehatan tubuh. Hasil uji fitokimia yang dilakukan oleh (Mutiara et al., 2013) menyatakan bahwa pada buah bit (Beta vulgaris L) terdapat senyawa fenol, alkaloid, saponin, flavonoid, sterol dan triterpen yang merupakan sumber alami antioksidan.

\section{MATERI DAN METODE}

\section{Tempat dan Waktu}

Penelitian dilaksanakan di Laboratorium Ilmu dan Teknologi Pengolahan Susu Program Studi Peternakan Fakultas Pertanian Universitas Syiah Kuala Darussalam Banda Aceh. Analisis aktivitas antioksidan dilakukan di Laboratorium Analis Pangan Program Studi Teknologi Hasil Pertanian Fakultas Pertanian Universitas Syiah Kuala penelitian berlangsung pada tanggal 20 Januari 2020 sampai 26 Januari 2021. 


\section{Materi, Bahan, dan Alat}

Bahan- bahan yang digunaan dalam penelitian ini adalah susu kambing yang diambil dari Usaha Dagang Abi Makmur Sentosa, Buah bit diproleh seputar pasar Penayong Banda Aceh, sedangkan starter Lactobacillus ramnosus diproleh dari Universitas Gajah Mada.

Alat yang digunakan dalam penelitian ini adalah laminar flow Merk Sanyo, autoklaf Merk Sanyo, inkubator Merk Sanyo, timbangan digital Merk Acadapter, Merk IKA, waterbath, buret, pH meter, lemari pendingin mikropipet, mikrotip, spektrofotometer, gelas ukur $500 \mathrm{ml}$, tabung reaksi, elemeyer $200 \mathrm{ml}$ dan elemeyer $500 \mathrm{ml}$, lampu spirtus, botol sampel $250 \mathrm{ml}$, kertas saring, jucer, sedok.

\section{Rancangan Penelitian}

Penelitian ini menggunakan metode Rancangan Acak Lengkap (RAL) yang terdiri dari 5 perlakuan dan 4 ulangan sehingga diperoleh 20 unit percobaan Adapun perlakuan yang diberikan antara lain: P0: (kontrol) $0 \%$ jus buah bit, P1: $2 \%$ jus buah bit, P2 :4\% jus buah bit, P3: 6\% jus buah bit, P4: 8\% jus buah bit. Data yang diperoleh dianalisis menggunakan Analysis of Variance (ANOVA), jika terdapat perbedaan antara perlakuan dilanjutkan dengan uji jarak berganda Duncan (Steel et al.,1995).

\section{Parameter Penelitian Uji pH}

Pengukuran $\mathrm{pH}$ dilakukan dengan menggunakan alat $\mathrm{pH}$ meter, $\mathrm{pH}$ meter dikalibrasi terlebih dahulu dengan larutan buffer $\mathrm{PH} 4$ dan 7. Kemudian bersihkan elektroda dengan aquades dan dikeringkan dengan menggunakan tissue, selanjutnya masukan sampel ke dalam beaker glass sebanyak $10 \mathrm{ml}$, kemudian elektroda $\mathrm{pH}$ meter dimasukan ke dalam beaker glass yang berisi sampel. Amati nilai $\mathrm{pH}$ yang tertera pada $\mathrm{pH}$ meter kemudian dicatat, selanjutnya elektroda harus dicuci dengan aquades dan dikeringkan menggunakan tissue sebelum dimasukkan sampel berikutnya.

\section{Analisis kadar Vitamin C Susu Kambing Fermentasi}

Sampel ditimbang sebanyak 5 gram, selanjutnya dimasukkan ke dalam labu ukur dan tambahkan aquades. Filtrat dihomogenkan kemudian disaring menggunakan kertas saring. Filtrat yang diperoleh diambil sebanyak $25 \mathrm{ml}$ kemudian dimasukkan ke dalam erlenmayer, kemudian $1 \mathrm{ml}$ amilum $1 \%$ ditambahkan ke dalam erlenmayer dihomogenkan selanjutnya dititrasi dengan larutan iodine standar 0,01 N hingga berubah warna (Kukuh dan Fitri 2015). Analisis vitamin $\mathrm{C}$ dapat dihitung dengan rumus sebagai berikut:

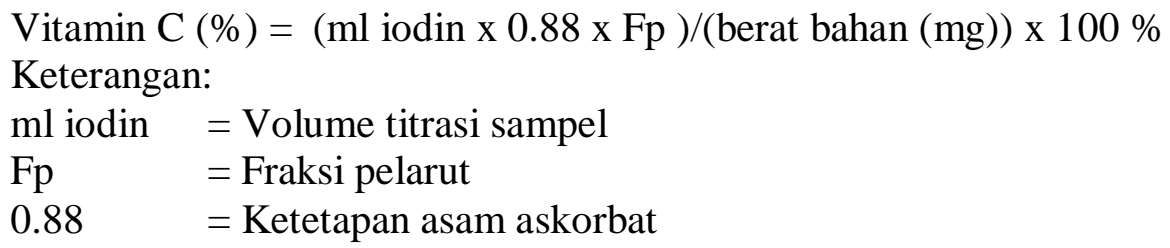




\section{Uji Aktivitas Antioksidan dengan Metode $\mathrm{IC}_{50}$}

Masing-masing konsentrasi diuji aktivitas antioksidan menggunakan metode Sumiati (2012). Sampel sebanyak $1 \mathrm{ml}$ ditambahkan $1 \mathrm{ml}$ DPPH yang dilarutkan dalam ethanol $4 \mathrm{ml}$ sampai muncul warna ungu pada sampel. DPPH digunakan sebagai blanko yang diperlakukan sama seperti sampel. Selanjutnya sampel dihomogenkan menggunakan vortex, diinkubasi di ruang gelap selama 30 menit dan selanjutnya dengan spektrofotometer pada gelombang 517 absorbansinya dapat dibaca. Penentuan nilai inhibisi untuk mengetahui nilai aktivitas antioksidan pada sampel ditentukan dengan menggunakan rumus berikut (Mukherjee, 2014).

$\% \mathrm{AA}=($ Absorbansi kontrol - Absorbansi sampel $) /($ Absorbansi kontrol $) \times 100 \%$ Keterangan:

Absorbansi sampel : Absorbansi DPPH setelah direaksikan dengan sampel

Absorbansi kontrol : Absorbansi DPPH tanpa sampel

DPPH :1,1-difenil-2-pikrilhidra-zil

Selanjutnya, nilai IC50 dihitung dengan menggunakan rumus persamaan regresi. IC50 adalah konsentrasi yang dibutuhkan untuk mereduksi DPPH sebesar 50\%. Hal ini bertujuan untuk mendapatkan konsentrasi yang lebih optimal sebagai antioksidan dalam menekan radikal bebas. IC50 dihitung dengan metode regresi linear, konsentrasi sampel sebagai sumbu $\mathrm{x}$ dan $\%$ inhibisi sebagai sumbu $\mathrm{y}$.

Dari persamaan $y=a+b x$ dapat dihitung IC50 dengan menggunakan rumus:

$\mathrm{y}=\mathrm{a}+\mathrm{bx}$

$50=\mathrm{a}+\mathrm{bx}$

(x) $\operatorname{IC50}=((50-a) / b)$

\section{HASIL DAN PEMBAHASAN}

\section{Nilai Potensial Hidrogen (pH)}

Berdasarkan hasil analisis sidik ragam data yang diproleh menunjukan rataan nilai $\mathrm{pH}$ susu kambing fermentasi menggunakan Lactobacillus rhamnosus dan penambahan jus buah bit dengan persentase yang berbeda dapat dilihat pada Gambar 4 berikut ini.

Gambar 1 menunjukkan bahwa penambahan jus buah bit memiliki pengaruh sangat nyata $(\mathrm{P}<0,01)$ terhadap penurunan nilai $\mathrm{pH}$ susu kambing fermentasi. Dari hasil uji jarak berganda Duncan menunjukkan bahwa nilai $\mathrm{pH}$ susu kambing fermentasi tertinggi terdapat pada P0 (tanpa penambahan jus buah bit) yaitu 4,13 sedangkan nilai $\mathrm{pH}$ susu kambing fermentasi terendah terdapat pada P2 (dengan penambahan jus buah bit $4 \%$ ) yaitu 4,05 . Sesuai dengan pendapat Pradana et al. (2018) yang menyatakan bahwa penambahan jus buah bit dalam pembuatan susu fermentasi mampu menurunkan $\mathrm{pH}$ susu fermentasi. Hal ini dikarenakan buah bit mengandung glukosa dan fruktosa yang cukup tinggi yaitu 10 gram per 100 gram bahan (Pasca, 2016) di mana glukosa dan fruktosa tersebut akan menambah substrat yang akan dimanfaatkan oleh BAL untuk menghasilkan asam laktat. Menurut James (2005) bahwa pH susu fermentasi yang baik berkisar antara 4,05- 4,5. 


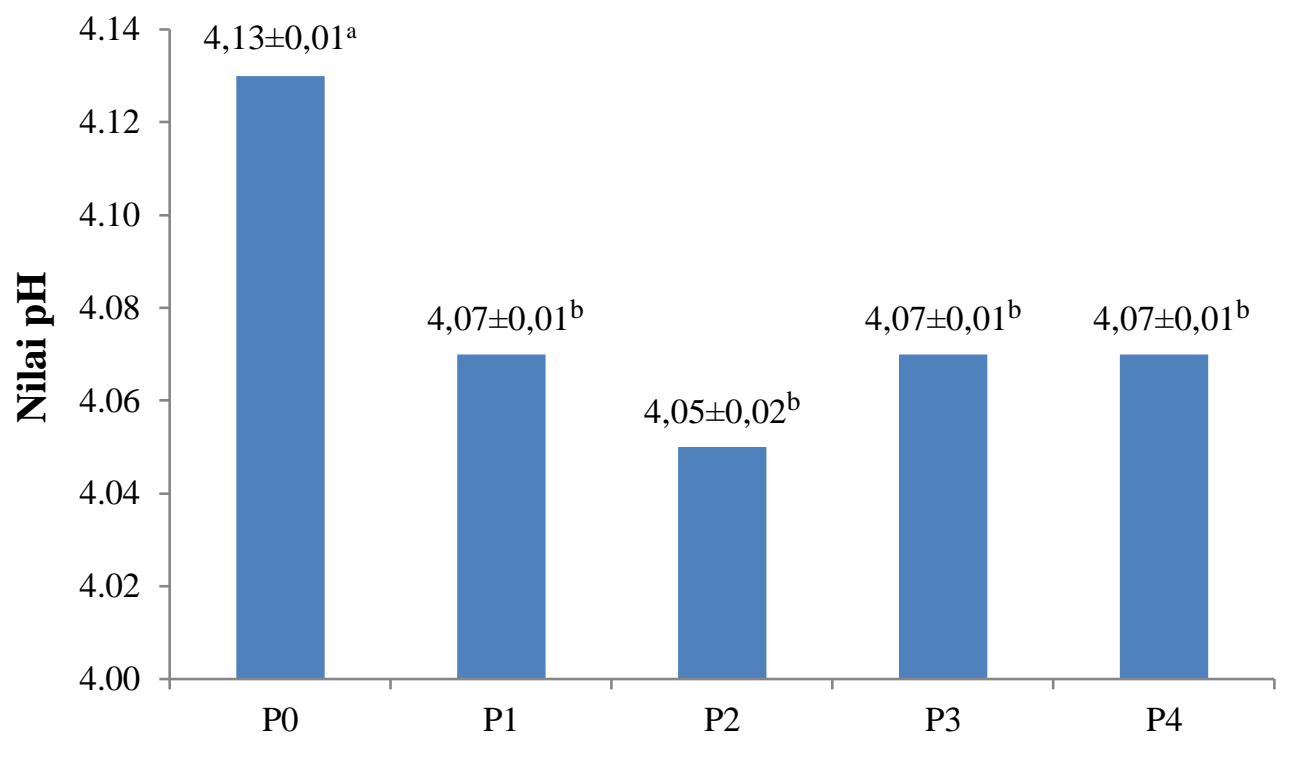

\section{Persentase Jus Buah Bit}

Gambar 1. Nilai pH susu kambing fermentasi menggunakan Lactobacillus rhamnosus dan penambahan jus buah bit.

Keterangan: $\mathrm{P} 0=$ kontrol (susu fermentasi tampa penambahan jus buah bit), $\mathrm{P} 1=2 \%$ jus buah bit, $\mathrm{P} 2=4 \%$ jus buah bit, $\mathrm{P} 3=6 \%$ jus buah bit $\mathrm{P} 4=8 \%$ jus buah bit, setiap perlakuan ditambahkan $5 \%$ Lactobacillus rhamnosus.

\section{Rataan Nilai Kadar Vitamin C}

Vitamin $\mathrm{C}$ merupakan vitamin yang berperan penting sebagai antioksidan yang mampu meredam radikal bebas di dalam tubuh. Sumber vitamin $C$ umumnya terdapat pada bahan pakan nabati, seperti sayuran dan buah - buahan (Cakrawati, 2012). Berdasarkan hasil analisis kadar vitamin $\mathrm{C}$ susu kambing fermentasi menggunakan Lactobacillus rhamnosus dan penambahan jus buah bit dengan persentase berbeda dapat dilihat pada Gambar 5.

Hasil analisis sidik ragam memperlihatkan bahwa penambahan jus buah bit tidak berpengaruh nyata $(\mathrm{P}>0.05)$ terhadap kadar vitamin $\mathrm{C}$ susu kambing fermentasi. Menurut Direktorat Gizi Depkes RI (2005), disebutkan bahwa per 100g buah bit mengandung $4.9 \mathrm{mg}$ vitamin $\mathrm{C}$, namun pada penelitian ini nilai raataan kadar vitamin $\mathrm{C}$ yang diproleh hanya berkisar antara $0.05-0.07 \mathrm{mg}$ per $100 \mathrm{~g}$ susu fermentasi. Rendahnya kadar vitamin C pada susu fermentasi disebabkan pada proses pembuatan susu fermentasi jus buah bit dipasteurisasi terlebih dahulu dengan suhu $75^{\circ} \mathrm{C}$ sehingga kandungan vitamin $\mathrm{C}$ pada buah bit rusak. Hal ini sejalan dengan pendapat Pertiwi dan susanto (2014), yang menyatakan bahwa vitamin C (asam askrobat) sifatnya sangat sensitif terhadap pengaruh luar penyebab kerusakan seperti suhu, oksigen dan katalisator logam. 


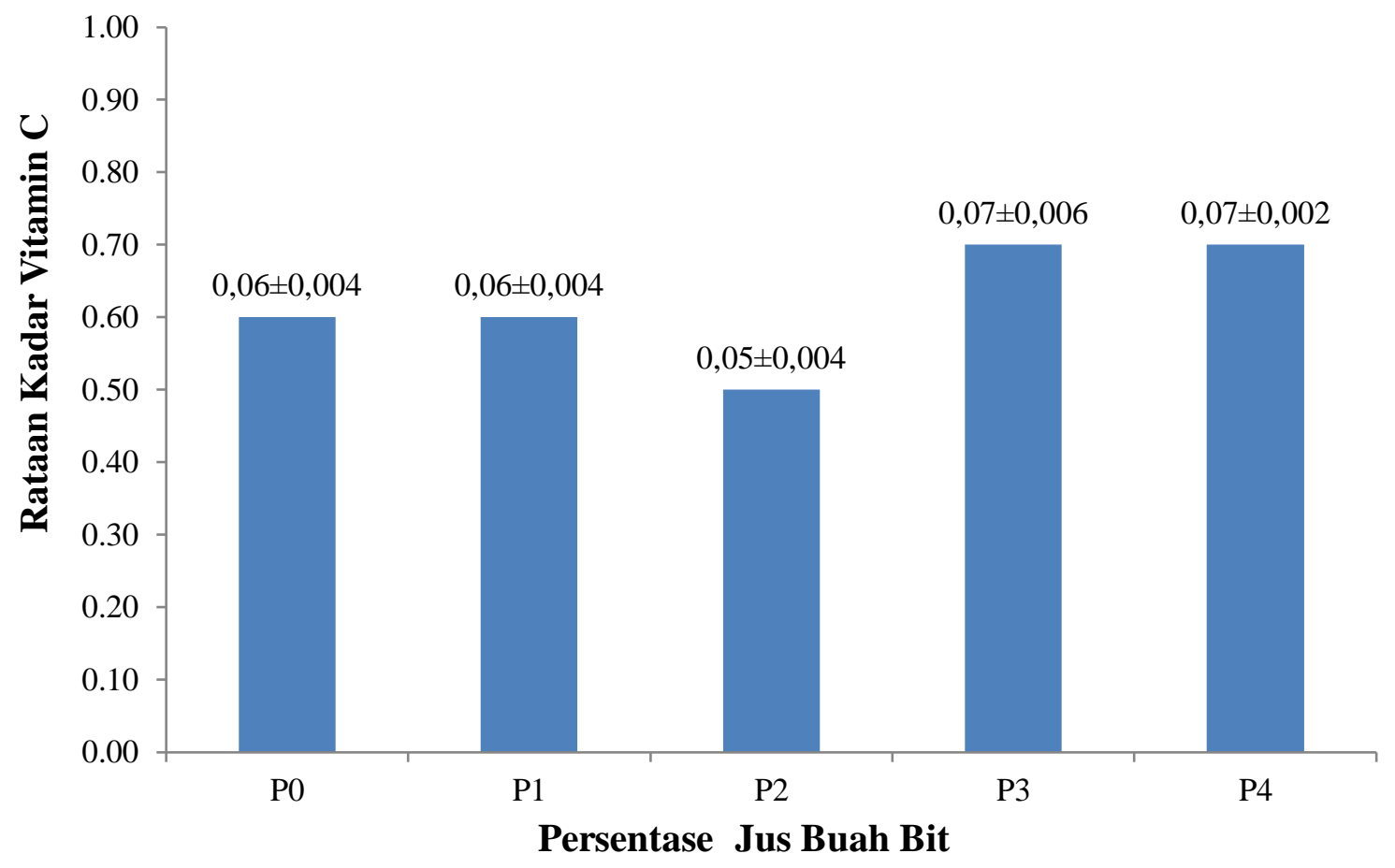

Gambar 2. Rataan kadar vitamin C susu kambing fermentasi menggunakan Lactobacillus rhamnosus dan penambahan jus buah bit.

Keterangan: $\mathrm{P} 0=$ kontrol (susu fermentasi tampa penambahan jus buah bit), $\mathrm{P} 1=2 \%$ jus buah bit, $\mathrm{P} 2=4 \%$ jus buah bit, $\mathrm{P} 3=6 \%$ jus buah bit $\mathrm{P} 4=8 \%$ jus buah bit, setiap perlakuan ditambahkan 5\% Lactobacillus rhamnosus.

\section{Aktivitas Antioksidan}

Dalam istilah pangan antioksidan adalah zat yang mampu mencegah terjadinya proses oksidasi yang dapat menyebabkan kerusakan pada bahan pagan (Pihlanto, 2006). Sampel susu kambing fermentasi menggunakan Lactobacillus rhamnosus dan penambahan jus buah bit direaksikan dengan larutan DPPH (2,2-difenil-1-pikrilhidrazil) mengalami perubahan warna larutan ungu menjadi berwarna kuning, selanjutnya diabsorbansikan pada panjang gelombang $517 \mathrm{~nm}$. Adanya senyawa yang dapat mendonorkan atom hydrogen menyebabkan terjadinya perubahan warna larutan DPPH dari ungu menjadi berwarna kuning pucat (Molyneux, 2004).

Nilai $\mathrm{IC}_{50}$ diproleh dengan menggunakan persamaan garis linier yang menyatakan hubungan antara konsentrasi sampel sebagai absis (sumbu $\mathrm{X}$ ) terhadap nilai persen inhibisi antioksidan sebagai ordinatnya (sumbu Y) (Purwaningsih, 2012). Semakin kecil nilai IC 50 suatu sampel uji maka semakin besar peredaman terhadap DPPH. Hasil uji aktivitas antioksidan $\mathrm{IC}_{50}$ dapat dilihat pada Tabel 1.

Kisaran aktivitas antioksidan $\mathrm{IC}_{50}$ diproleh pada penelitian ini berkisar antara 71,437 ppm sampai 101,465 ppm. Berdasarkan Tabel 1 diatas terlihat bahwa tanpa penambahan jus buah bit menghasilkan nilai $\mathrm{IC}_{50}$ sebesar $101,465 \mathrm{ppm}$. Selanjutnya diikuti oleh perlakuan P1, P2, P3, P4 berturut-turut dengan nilai $\mathrm{IC}_{50}$ sebesar 79,874 ppm, 79,002 ppm, 72,520 ppm, dan 71,437 ppm. Menurut Molyneux (2004), berdasarkan nilai $\mathrm{IC}_{50}$ aktivitas antioksidan dapat digolongkan menjadi lima golongan, yaitu sangat kuat $\left(\mathrm{IC}_{50}<50 \mathrm{ppm}\right)$, kuat $\left(50 \mathrm{ppm}<\mathrm{IC}_{50}\right.$ 
$>100 \mathrm{ppm})$, sedang $\left(100 \mathrm{ppm}<\mathrm{IC}_{50}>150 \mathrm{ppm}\right)$, lemah $\left(150 \mathrm{ppm}<\mathrm{IC}_{50}>200 \mathrm{ppm}\right)$, dan sangat lemah $\left(\mathrm{IC}_{50}>200 \mathrm{ppm}\right)$.

Tabel 1. Nilai $\mathrm{IC}_{50}$ susu kambing fermentasi menggunakan lactobacillus rhamnosus dan penambahan jus buah bit

\begin{tabular}{cccc}
\hline Sampel & Persamaan garis & Nilai Y & Nilai X atau IC $\mathbf{5 0}_{\mathbf{5}}$ \\
\hline P0 & $\mathrm{y}=0,5088 \mathrm{x}+1,6254$ & 50 & 101,465 \\
$\mathbf{P 1}$ & $\mathrm{y}=0,5813 \mathrm{x}-3,5689$ & 50 & 79,874 \\
$\mathbf{P 2}$ & $\mathrm{y}=0,7456 \mathrm{x}-8,9046$ & 50 & 79,002 \\
$\mathbf{P 3}$ & $\mathrm{y}=0,5618 \mathrm{x}-9,258$ & 50 & 72,520 \\
$\mathbf{P 4}$ & $\mathrm{y}=0.5901 \mathrm{x}-7,844$ & 50 & 71,437
\end{tabular}

Keterangan: $\mathrm{P} 0=$ kontrol (susu fermentasi tampa penambahan jus buah bit), $\mathrm{P} 1=2 \%$ jus buah bit, $\mathrm{P} 2=4 \%$ jus buah bit, $\mathrm{P} 3=6 \%$ jus buah bit $\mathrm{P} 4=8 \%$ jus buah bit, setiap perlakuan ditambahkan 5\% Lactobacillus rhamnosus.

Hasil yang diproleh pada P1, P2, P3, P4 termasuk dalam golongan antioksidan kuat (50 ppm < $\mathrm{IC}_{50}>100 \mathrm{ppm}$ ), sedangkan P0 termasuk dalam golongan antioksidan sedang (100 ppm $\left.<\mathrm{IC}_{50}>150 \mathrm{ppm}\right)$. Lactobaciluss rhamonosus dan penambahan jus buah bit bekerja dengan baik dalam meningkatkan aktivitas antioksidan, dengan penambahan buah bit mampu mengubah golongan antioksidan susu fermentasi dari golongan antioksidan sedang menjadi golongan antioksidan kuat. Peningkatan antioksidan disebabkan terbentuknya asam laktat pada proses fermentasi susu. Menurut Yu et al. (2002), asam laktat pada susu kambing mengandung $\alpha$ - hidroxyacid (AHA) yang berfungsi sebagai antioksidan. Selain itu buah bit juga mengandung zat betasianin, flavonoid, fenol, saponin sterol, dan triterpen yang berperan sebagai antioksidan. Penelitian Mutiara et al. (2016), menyatakan bahwa buah bit memiliki aktivitas antioksidan yang kuat. Senyawa antioksidan dalam buah bit dan asam laktat yang dihasilkan oleh bakteri asam laktat berperan sebagai pendonor atom hydrogen pada radikal bebas sehingga dapat meredam radikal bebas.

\section{Hubungan Aktivitas Antioksidan dan Nilai pH}

Hasil analisis regresi linear yang memperlihatkan hubungan antara aktivitas antioksidan dan nilai pH susu kambing fermentasi menggunakan Lactobacillus rhamnosus dan penambahan jus buah bit dapat dilihat pada Gambar 3.

Dapat dilihat dari nilai koefisien determinasi $\left(\mathrm{R}^{2}\right)$ yang memperlihatkan parameter nilai $\mathrm{pH}$ memiliki pengaruh $75 \%$ terhadap nilai aktivitas antioksidan, sementara $25 \%$ lainya dipengaruhi oleh faktor lain. Korelasi (r) menunjukan nilai -0.866 Artinya korelasi antara nilai pH dan aktivitas antioksidan memiliki hubungan negatif yang sangat kuat. Hal ini sesuai dengan yang dikemukakan oleh Jonathan (2009), bahwa kriteria keeratan hubungan koefisien korelasi dengan nilai $-0,75--0,990$ memiliki hubungan negatif yang sangat kuat. Yang berarti meningkatnya aktivitas antioksidan $\left(\mathrm{IC}_{50}\right)$ diikuti dengan penurunan nilai $\mathrm{pH}$. 


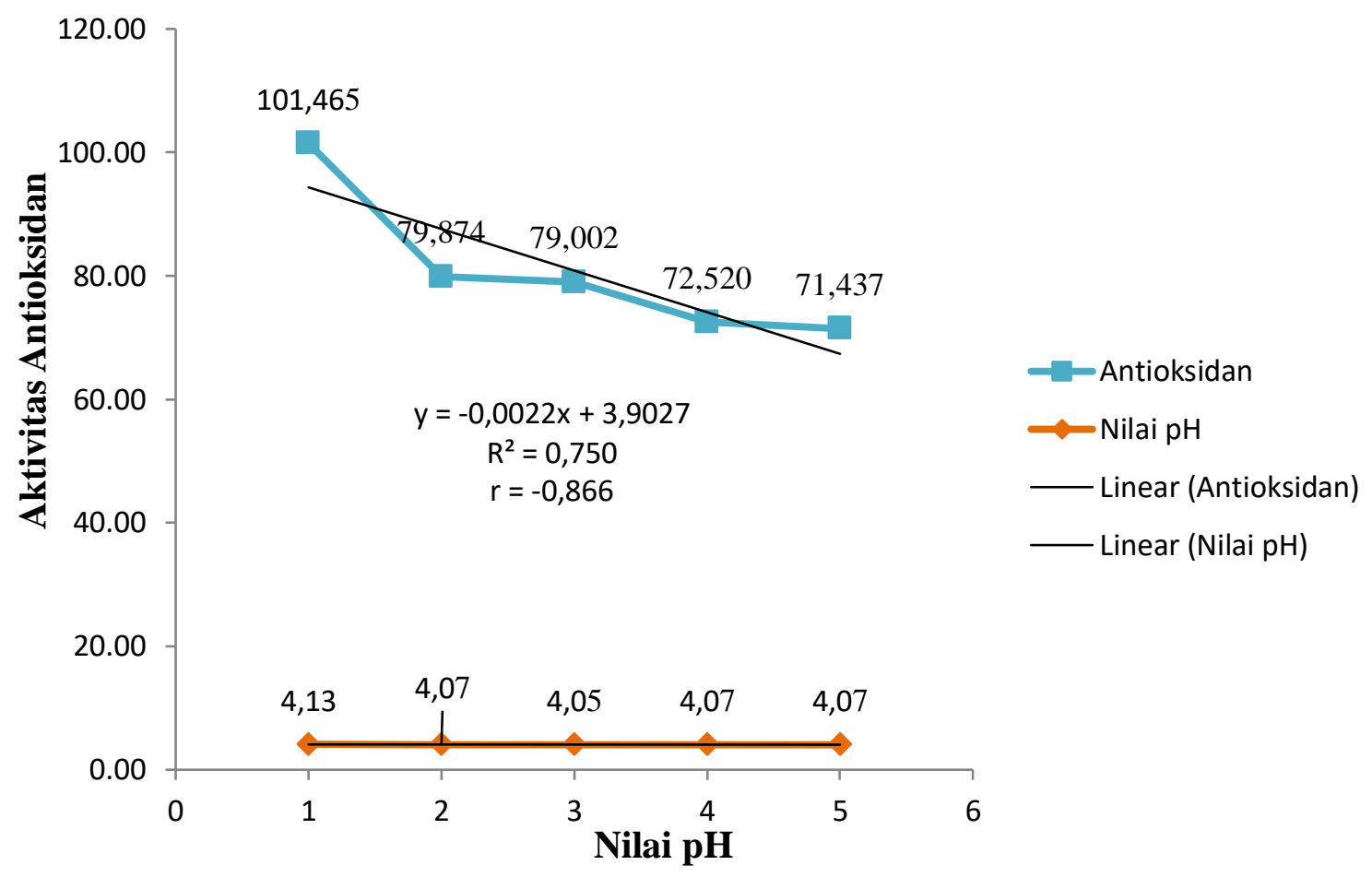

Gambar 3. Hubungan aktivitas antioksidan dan nilai pH susu kambing fermentasi menggunakan Lactobacillus rhamnosus dan penambahan jus buah bit.

\section{KESIMPULAN DAN SARAN}

\section{Kesimpulan}

Berdasarkan hasil penelitian ini menunjukkan bahwa dengan penambahan jus buah bit berpengaruh sangat nyata $(\mathrm{P}<0,01)$ terhadap nilai $\mathrm{pH}$ susu kambing fermentasi menggunakan Lactobacillus rhamnosus, di mana pada setiap perlakuan memiliki nilai $\mathrm{pH}$ lebih rendah dibanding dengan P0 (kontrol). Pada aktivitas antioksidan menunjukkan dengan penambahan jus buah bit mampu meningkatkan golongan aktivitas antioksidan $\left(\mathrm{IC}_{50}\right)$ susu kambing fermentasi dari golongan antioksidan sedang menjadi golongan antioksidan kuat. Sedangkan pada hasil uji kadar vitamin $\mathrm{C}$ menunjukkan bahwa penambahan jus buah bit tidak berpengaruh nyata $(\mathrm{P}>0.05)$ terhadap kadar vitamin $\mathrm{C}$ susu kambing fermentasi, diduga hal ini disebabkan oleh suhu pasteurisasi yang terlalu tinggi.

\section{Saran}

Berdasarkan penelitian yang telah dilakukan, penulis menyarankan sebaiknya ada penelitian lanjutan mengenai aktivitas antioksidan, kadar vitamin $\mathrm{C}$ dan derajat keasaman susu fermentasi dengan penambahan jus buah bit yang difermentasi dengan lactobacillus rhamnosus dan kombinasi bakteri probiotik lainya dengan suhu pasteurisasi yang lebih rendah. 


\section{DAFTAR PUSTAKA}

Abubakar, M.A.S., Z, Hassan, M., Muftah, A., Imdakim dan Sharifah, N.R.S.A. 2012. Antioxidant activity of lactic acid bacteria (LAB) fermented skim milk as determined by 1,1-diphenyl-2-picrylhydrazyl (DPPH) and ferrous chelating activity (FCA). African Journal of Microbiology Research 6 (34): 6358-6364.

Ahmad, R., Munim, A dan Elya, B. 2012. Study of antioxidant activity withreduction of free radical DPPH andxanthine oxidase inhibitor of the extractRuellia tuberosa Linn Leaf. International Research Journal of Pharmacy. 3(11).

Andersen, Q.M. dan Markham, K.R. 2006. Flavonoid : Chemistry, Biochemistry and aplication. CRC Press. USA. 2-11.

Bahar, B. 2008. Minuman Susu Fermentasi dengan Segudang Khasiat untuk Kesehatan. PT Gramedia Pustaka Utama, Jakarta.

Cakrawati, Dewi. 2012. Bahan Pangan, Gizi, dan Kesehatan. Alfabeta, Bandung.

Direktorat Gizi Depkes RI.2005. Daftar komposisi bahan makanan. Jakarta: Departemen Kesehatan, Jakarta.

Farnworth E. 2005. Kefir A Complex Probiotic.Food Science and Technology Bulletin. Functional Foods.2(1): 1-17

Forestier, C., C. De Champs, C., Vatoux, C dan Joly, B. 2001. Probiotic activities of Lactobacillus casei rhamnosus: in vitro adherenceto intestinal cells and antimicrobial properties. Res. Microbiol 152. 167-173.

Hadiwiyoto, S. 1994. Teori dan Prosedur Pengujian Mutu Susu Dan Hasil Olahannya. Liberty, Yogyakarta.

Hembing. 2008. Ramuan herbal penurun kolesterol. niaga swadaya, Jakarta.

James. 2005. Modern Food Microbiology. Cahoman and Hall Book, New York.

Jonathan, S. 2009. Statistik itu mudah, panduan lengkap untuk belajar komputasi statistic menggunakan SPSS 16. Univesitas Atma Jaya, Yogyakarta.

Khairina, D. 2008. Faktor-faktor yang berhubungan dengan status gizi. FKM UI Prees, Jakarta.

Lindmark M., dan H. Akesson, B. 2000. Antioxidative factors in milk. Br. J. Nutr. 84:103-110.

Moelijanto., Damayanti, R. dan Bernadius. 2002. Khasiat dan Manfaat Susu Kambing. Agromedia, Jakarta.

Molyneux, P. 2004. The use of DPPH for estimating antioxidant activity. Journal of Science and Technology. 26 (2): 211-219.

Mukherjee. 2014. An approach towards optimization of the extraction of polyphenolic antioxidants from ginger (Zingiber officinale). J Food Sci Techno. 51(11):3301-3308 
Mutiara, S., Kusumo, E dan Supartono, S. 2016. Identifikasi betasianin dan uji antioksidan ekstrak buah bit merah (Beta vulgaris L). Indonesian Journal of Chemical Science, 5(3), 217-220.

Mutiara, W. dan Heni P. 2013. Efektivitas ekstrak buah Beta vulgaris L. (Buah Bit) dengan berbagai fraksi pelarut terhadap mortalitas Larva aedes Aegypti. Loka Penelitian dan Pengembangan Penyakit Bersumber Binatang (P2B2). Ciamis

Napitupulu, N. R., A Kanti, T., Yulinery., Hardiningsih, R dan Julistiono, H. 1997. DNA plasmid Lactobaccilusasal makanan fermentasi tradisional bioteknologi pagan, Jurnal mikrobiologi tropis. 1: 91-196.

Pasca, F. P., Nurwantoro, N dan Pramono, Y. B. 2016. Total bakteri asam laktat, kadar asam laktat, dan warna yogurt drink dengan penambahan ekstrak bit (Beta vulgaris L.). Jurnal Aplikasi Teknologi Pangan, 5(4).

Pertiwi, M. F dan Susanto, W.H. 2014. Pengaruh proporsi (Buah: Sukrosa) dan Lama Osmosis Terhadap Kualitas Sari Buah Stroberi (Fragaria vesca L.). Jurnal Pangan dan Agroindustri 2(2):82-90.

Pihlanto, A. 2006. Antioxidative peptides derived from milk proteins. International Dairy Journal. 16:1306-1314.

Pradana, A. S., Srijuliani, E dan Risnantoko. 2018. Karakteristik kimia dan organoleptik yoghurt tempe dengan penambahan ekstrak buah bit (beta vulgaris L). In Prosiding Seminar Nasional Fakultas Pertanian. 1-1.

Purwaningsih, S. 2012. Aktivitas antioksidan dan komposisi kimia keong matah merah (Cerithidea obtuse). Ilmu Kelautan. 17(1) 39-48.

Saleh, E. 2004. Dasar Pengolahan Susu dan Hasil Ikutan Ternak. Program Studi Produksi Ternak. Fakultas Pertanian. Universitas Sumatera Utara, Medan.

Sen, S., Charaborty R., Sridhar C., Reddy Y S dan De B. 2010. Free Radicals, Antioxidants, Diseases and Phytomedicines. Current Status and Future Prospect Nitrogen Species. 3 (1): 1-100.

Steel, C.J. dan Torrie, J.H. 1995. Prinsip dan Prosedur Statistik. PT. Gramedia, Jakarta.

Sugiyono. 2007. Metode penelitian kuantitatif, kualitatif dan R\&D. Alfabeta, Bandung.

Sumiati, T. 2012. Pengaruh pengolahan senyawa antioksidan terhadap mutu cerna ikan mujair. J Sci IPB.2(4).

Suryandari, A. E dan Happinasari, O. 2015. Perbandingan kenaikan kadar Hb pada ibu hamil yang diberi Fe dengan Fe dan buah bit di wilayah kerja puskesmas purwokerto selatan. Jurnal Kebidanan. 7(01).

Sutama, I.G.M. 2009. Budiarsana. Panduan Lengkap Kambing dan Domba. Penebar Swadaya, Jakarta. 
Turan B. 2010. Role of Antioxidants in Redox Regulation of Diabetic Cardiorvascular Complications. Current pharmaceutical biotecnology. 11 (8): 819-836.

Wahyudi, M. 2006. Proses Pembuatan dan analisis mutu yogurt. Buletin Teknik Pertanian.11(1):12-16.

Werdhasari, A. 2014. Peran Antioksidan Bagi Kesehatan . Jurnal Biotek Medisiana Indonesia. . 3(2): 59-68.

Winarsi, H.2007. Antioksidan Alami dan Radikal Bebas. Kanisius, Yogyakarta.

Wulansari, A.N. 2018. Alternatif cantigi ungu (Vaccinium varigiaefolium) sebagai Antioksidan. Farmaka. 16(2).

Yu, R.J. dan E.J. Van Scott. Hydroxycarboxylic acids, N-acetylamino sugars and Nacetylamino acids. Skinmed. 1 (2):117-22. 